DANIEL MATO’

\title{
The multiple forms of racism and the challenges it poses to higher education system $\mathrm{s}^{2}$
}

Racism is an ideology according to which human beings are classifiable into "races" and some of them are "superior" to others. In Latin America, this ideology dates back to the colonial period. It is constitutive of the establishment of postcolonial republican States, continues in force, and its consequences especially affect the people and communities of indigenous and Afro-descendant peoples.

Although in many of the "Latin American" countries (an expression that at least silences the existence of indigenous and Afro-descendant peoples), openly discriminatory behavior towards indigenous and Afro-descendant individuals and communities is less common than in the past, at no time has it ceased to exist, and in some countries has even flared up in recent years.

This ideology permeates the hegemonic forms of common sense in all societies of the region and is permanently reproduced through various institutional norms, mechanisms and practices. Educational systems and the mass media play key roles in these processes, although these are not the only social areas in which this occurs.

In them, as in other social spaces, racism is not only expressed and exercised through "visible" social practices, which is what the expression of "racial discrimination" is

\footnotetext{
1 DANIEl MATO is a CONICET Principal Investigator, Director of UNESCO Chair in Higher Education, Indigenous Peoples and Afro-descendant Peoples in Latin America, Universidad Nacional Tres de Febrero. Email: dmato@untref.edu.ar

2 This article was originally published in http://www.alternautas.net/blog/2020/10/7/themultiple-forms-of-racism-and-the-challenges-it-poses-to-higher-education-systems. This text has been translated by Emilie Dupuits and Rebecca Hollender from the Original text in Spanish published in the journal De Prácticas y Discursos. Cuadernos de Ciencias Sociales (Universidad Nacional del Nordeste,

Argentina)

https://revistas.unne.edu.ar/index.php/dpd/article/view/4412
} 
usually limited to. It also operates through disadvantages accumulated over centuries, the existence of which has been "naturalized". These disadvantages are the result of inequities and forms of inequality and exclusion of an economic, political, and sociocultural nature, which are reproduced and multiplied through both prejudices and forms of "common sense", as well as through institutional norms, devices, and practices. The idea of "structural racism" is useful for referring to this set of factors in a comprehensive way. However, as discussed later in this text, it is analytically insufficient in serving as a basis for the design of concrete intervention initiatives that are potentially effective in eradicating racism from Higher Education systems.

Throughout history, colonial and postcolonial states have used education as a means to affirm and legitimize their dominance over indigenous and Afro-descendant peoples ${ }^{3}$. But for several decades, critical positions have been developing in a growing number of universities and other Higher Education Institutions (HEIs) in Latin America. Some of them go beyond the argumentative and guide specific practices in the areas of institutional construction, management, teaching, research and social connection ${ }^{4}$. This article seeks to contribute to the analysis of the different ways in which racism operates in Higher Education systems and the challenges it poses.

\section{Racism and Higher Education}

In Latin America, universities and other HEIs have played important roles both in the process of building homogenizing representations of the populations of the respective countries, and in the transformation of indigenous and Afro-descendant peoples into objects of study, even against their will. They have done so from Eurocentric research approaches that produced disqualifying representations of their

\footnotetext{
3 The expression "Latin America" was not part of the lexicon of the independence movements of the early nineteenth century. The idea of "Latinity" and its application as an adjective was proposed in 1836 by the French intellectual Michel Chevalier. "Latin America" as a compound name first appeared in a book by the Colombian intellectual José María Torres Caicedo in 1865 (Ardao, 1980).

${ }^{4}$ In this text, as in other previous ones, I use the expression "social bonding" in a generic way to refer to what in different institutional settings and work orientations, according to the cases, is usually named as "university extension" (expression that in some cases are accompanied by adjectives such as "two-way", or others), "action research" (in some cases also proposed as "participatory"), "service learning" (in some cases specified as "solidarity"), "dialogue of knowledge", "volunteering", and "university social responsibility", among other forms of university action (Mato, 2015).
} 
"races", ways of life, worldviews, future projects, knowledge and ways of producing them.

Advancing towards the eradication of racism in Higher Education has to be achieved in all areas of each of the respective societies. At the educational level, technicians and professionals are trained to occupy social, economic and political positions of great influence in the respective societies. Among other professionals, universities and other HEIs graduate teachers play key roles at all levels of educational systems. They also train professionals in social communication, sociology, political science, and related fields that play key roles in guiding public opinion trends. For these reasons, it must be added that universities and other HEIs not only constitute spaces for technical and professional training, but also for training citizens and public opinion.

Fortunately, in an increasing number of universities and other HEIs in Latin America, various intervention modalities have been deliberately oriented to transform not only the universities and other HEIs, but also, and comprehensively, the Higher Education systems (including those institutions, and also the norms, public policies, and institutional practices of public bodies with competence in this field), so that they respond appropriately to the needs, demands, and proposals of the multicultural societies which they form part of. It is a large set of very diverse experiences, some of which are developed in and from "conventional"5 institutions, intercultural institutions, and "own" institutions of indigenous or Afro-descendant organizations. It is beyond the scope of this text to offer a complete explanation of the characteristics of these experiences, their advances and challenges, and the collaborative relationships that they increasingly maintain among themselves, which have been documented and analyzed in some collective publications that offer specific studies on numerous particular cases (Baronnet and Bermúdez Urbina, coords., 2019; CGEIB, comp., 2004; Di Caudo, Llanos Erazo and Ospina Alvarado, coords., 2016; Hernández Loeza, Ramírez Duque, Manjarraz Martínez and Flores Rosas, coords., 2013; Mato, coord., 2008; 2009; 2015; 2016; 2017; 2018a; 2019).

\footnotetext{
5 In this text, as in previous ones, I call "conventional" the universities and other HEls that have not been created to respond to demands and proposals from indigenous peoples and Afrodescendants.
} 
The multiple forms of racism 140

\section{The multiple forms of racism and the challenges it poses to higher education systems}

To advance towards the eradication of racism in Higher Education, it is not only necessary to differentiate between racism and racial discrimination. It is also necessary to refine the analysis of the broad and relatively imprecise set of problems that are often referred to by the expression "structural racism". In order to design effective actions aimed at eradicating racism, it is necessary to analytically disaggregate this concept, without intending to establish some kind of absolute truth in this regard, but for operational purposes. This disaggregation could vary depending on whether one seeks to intervene in the field of Higher Education, or in other social spaces.

In order to intervene in the field of Higher Education systems, it is operationally useful to understand that there are structural factors, which are not specific to their systemic scope and which cannot be resolved in / from this, or at least not only in / from this, but that does not mean that its importance can be ignored; on the contrary, it is necessary to find ways to contribute to responding to them.

Examples of this type of factor are the historically accumulated disadvantages that stem from the dispossession of the territories of indigenous peoples that began during the European invasion and colonization, and continued in the post-colonial republics. This forced them to move, and in some cases they were forcibly displaced by military forces. As a consequence, they were deprived of their food sources and shelter, and were forced to seek new forms of livelihood. In many cases, they were also forced to work in mines, mills and estates, in extremely disadvantageous conditions. Similar problems have affected Afro-descendant communities who, after fleeing slavery, or when slavery ended, established territorial areas of subsistence (quilombos, cumbés, or palenques, among other denominations, in various countries) from which in many cases they were later expelled. With variations in form, these types of problems continue to affect communities of indigenous and Afro-descendant peoples, as a consequence of the advance of agricultural and mining operations, urban and tourist developments, and other activities that also usurp their territories, destroy and / or contaminate rivers and wetlands, throughout Latin America. The limited advances in the recognition of territorial rights of these peoples achieved in some Latin American countries are generally insufficient to ensure the sustainability of the ways of life of these communities. Furthermore, the defense of these rights against the voracity and violence of powerful economic sectors often 
demands permanent actions by the respective communities, which are frequently criminalized by the States (UN, 2002, 2005).

These factors, in addition to health problems, difficulties in accessing justice, health services and quality basic education, usually motivate forced displacement of these populations or their members towards urban centers. Their insertion in these contexts usually occurs under even more disadvantageous conditions than those suffered by other social sectors affected by precarious conditions and economic poverty. This is generally due to their status as migrants relatively lacking in practical knowledge about their new places of residence, as well as sufficiently effective social support networks, and also - of course - due to cultural differences, and sometimes also linguistic differences.

These complex processes with a long historical evolution have different types of consequences, but in relation to the educational field they are expressed, for example, in the fact that illiteracy rates, as well as those of incomplete primary or secondary education, register higher values among the indigenous and afro-descendant peoples than those corresponding to other sectors of the population of each of the countries of the region. In this sense, these types of problems generate inequality and exclusion, and constitute structural causes of the low participation of indigenous and Afrodescendant people among students, teaching bodies, authorities and officials of universities and other HEIs.

There is relatively little that can be done directly and immediately from universities and other HEIs to reverse these problems. On the other hand, it is possible to contribute to doing so from a longer term perspective, through the training that these institutions provide. Students of all the races must learn about these historical and contemporary processes and understand and value the need to respond to them. It is necessary to dedicate research initiatives to the study of these problems and to the design of responses to them. It is also feasible and recommended to develop university social bonding programs aimed at strengthening the affected communities, and together with them, the primary and secondary educational institutions that serve them. With this task, it is also possible to establish the headquarters of universities and other HEIs in localities close to the communities of those towns. Additionally, affirmative action programs should be created that stimulate and favor the entry, successful training and graduation of students from these towns, as well as the incorporation of teachers and officials from these same origins. These types of 
measures can contribute to responding to these problems of structural racism, even if they are not sufficient for solving them.

Some universities and other HEIs in various countries in the region have been developing valuable initiatives of the type mentioned for some time. But they usually do it with limited resources, without categorically demanding from governments the budgets necessary to sustain them. In this sense, there seems to be a serious omission. Both governments, universities and other HEIs seem to forget that ensuring educational opportunities for people and communities of these peoples, at all levels, under equitable conditions, and that are appropriate to their contexts and interests, constitute rights established in multiple international conventions and in the national constitutions and laws of most countries in the region ${ }^{6}$. Advancing in this direction may be more viable if, in addition to focusing on socially structural problems, efforts are made to resolve those of a systemic and institutional nature.

There are other factors that can be characterized as systemic, as they are specific to the norms, policies and practices of each higher education system in particular. The systemic factors that ensure the reproduction of racism are generally not evident. For example, current regulations establish the need to have a university or higher education degree to teach in institutions at that level, which in principle can be considered a "normal" requirement. The problem is that this type of regulation prevents wise people from indigenous peoples who, despite not having a title, for example, are the best, if not the only ones, who manage ancestral knowledge of therapeutic uses of certain plant species, or of management and improvement of some seeds and tubers. These types of regulations also result in, when these people are allowed to teach, them not being recognized and paid as teachers on equal terms with those who hold university degrees.

These types of provisions express the monocultural nature of Higher Education systems, which despise valuable knowledge for not being academically certified and in doing so not only deprive Higher Education systems of them, but also reproduce forms of "invisible" racism. The existence of these types of ethnocentric,

\footnotetext{
${ }^{6}$ See especially:

- Organización de las Naciones Unidas (1967) Convención Internacional sobre Eliminación de Todas las Formas de Discriminación Racial https://www.ohchr.org/SP/Professionallnterest/Pages/CERD.aspx

- Organización Internacional del Trabajo (1989) Convenio sobre pueblos indígenas y tribales (Convenio Nro. 169) https://www.ilo.org/dyn/normlex/es/f?p=NORMLEXPUB:12100:O::NO::P12100_LO_CODE:C169
} 
monocultural and therefore racist norms, contrasts with the search for these types of knowledge, and specialists in them, by pharmaceutical and agro-industrial corporations, which dedicate efforts to obtain and patent them for their benefit.

Something similar, and even more serious, occurs with respect to the best speakers of the languages of indigenous peoples. Thanks to initiatives by teachers and researchers who are aware of the value of these specialists and to the support of officials and authorities, solutions to these systemic problems are being tried in some universities and other HEIs, but, although valuable and potentially generating long term solutions, these initiatives are only compensatory. There should be appropriate standards at the systemic level.

Similarly, systemic and institutional regulations and cultures have constrained the training spaces of many disciplines to learning in the classroom, wasting valuable opportunities that arise outside of them. However, in some careers it is almost inconceivable to graduate without interning in non-university settings. The fields of Agronomy and Ecology are perhaps the best example of this type, although in them it is also possible to train only within classrooms and laboratories, without doing field work. Practice-based learning processes are also vital in the training of medical and dental professionals. Although in these cases the practices are often carried out exclusively in "academically" controlled spaces, such as doctor's offices, laboratories or operating rooms. But in certain specialties of these fields in some universities, efforts are made to complement training with field experiences, and in some countries the so-called "social service" is a requirement to graduate in these disciplines. In a good number of cases, these types of activities are carried out in communities of indigenous and Afro-descendant peoples. This in itself does not necessarily mean that racism issues have been resolved. On the contrary, given the work guidelines, in many cases they end up reinforcing it, but in others, these experiences open up paths of knowledge, awareness and commitment.

It is necessary to strengthen these types of positive experiences, and also to train all teachers and students in these disciplines to ensure that all experiences of this type, and not just some, are positive for the eradication of racism. To respond to these types of challenges, it is not enough to have initiatives at the level of departments, faculties or institutions, because their actions are subject to evaluations by evaluation and accreditation bodies. It is necessary to have appropriate systemic regulations, which not only rhetorically recognize their importance and value, but also foresee 
ways to accredit them as part of the training courses and ensure the availability of resources to carry them out.

Except in some innovative universities, curiously, in the curricula of most humanities and social sciences fields it is less common to see training modalities beyond reading and classroom work, than in the aforementioned professional training. However, the development of learning experiences in the field and in practice, and collaborative work with various types of communities (including those of indigenous peoples and Afro-descendants) constitute work modalities that have been gaining ground for several decades in a number of growing careers in these fields. However, it frequently happens that these innovative forms of learning (innovative not only from a didactic point of view, but also epistemological, ethical and sensitive) are usually developed somewhat contrary to systemic regulations and institutional study plans. This type of obstacle ends up demanding extra workloads for teachers and students that are not recognized by the institutions, because these in turn do not have the validation of the evaluation and accreditation bodies.

Finally, there are other types of factors specific to the designs and institutional practices of each university or HEI in particular. Examples of these types of factors that can be characterized as institutional racism are those associated with the degrees offered by each institution, their study plans, and institutionally creditable learning activities, among others. There are few universities and other HEIs that design and offer degrees and study plans that are relevant to the cultural diversity of the territories in which they are established, and even fewer offer educational opportunities relevant to the needs and demands of village communities and indigenous and afrodescendants peoples. This is especially worrying in the cases of some disciplines such as health care, in which intercultural training is only very exceptionally offered. In Latin America, where according to the most recent census data, $8 \%$ of the population recognizes itself as a member of some indigenous people and $21.5 \%$ does so as an Afro-descendant, most of the Medicine and Nursing professionals graduate without Having training on the representations of health and disease of indigenous and Afrodescendant peoples, they also do not receive training on their therapeutic practices, and sometimes on diseases that are endemic to these populations.

The analytical differentiations between structural, systemic, and institutional factors, explained in previous paragraphs, should not make us lose sight of the fact that all of them are articulated among themselves. Nor can it be ignored that these factors are updated and reproduced through the practices of numerous social actors whose 
existence and practices are not limited to the field of Higher Education, especially regarding structural and systemic ones. Just as examples, it is worth mentioning that in the configuration of these factors and the challenges they pose to the Higher Education systems, according to case studies, actors as diverse as the mass media, ranking companies, political parties, business chambers, pharmaceutical and agroindustrial corporations, professional associations of the most diverse branches, and/or teaching unions, among others, participate in direct or indirect ways from universities.

In order to advance towards the eradication of racism, it is necessary to do so in educational systems, and particularly in Higher Education, for the reasons explained at the beginning of this text about its significant incidence in various social fields.

In order to design modes of intervention that eradicate racism from Higher Education systems, and with it from the respective societies, it is necessary to analyze in a disaggregated way the social representations, norms, mechanisms, institutional practices and other factors that permanently update and reproduce it and the social actors involved in these processes.

Moving forward with these purposes in universities and other HEIs may be more feasible than achieving it directly on a systemic or structural scale, but it is not enough. The magnitude and complexity of the problem requires directing efforts beyond the academic sphere, it is necessary to influence public opinion and political

decision-making instances. But, at the same time, if we do not succeed in eradicating racism in Higher Education, we will hardly succeed in doing so in each of our societies as a whole. For these reasons, the final declaration of the 3rd Regional Conference on Higher Education in Latin America and the Caribbean, among other recommendations, explicitly commissioned "Higher education institutions must guarantee the effective enjoyment of these rights [by indigenous and Afro-descendant peoples] and educate the population in general, and particularly their communities, against racism and all forms of discrimination and related forms of intolerance."

\section{Cultural Diversity, Racism and Interculturality in the $3^{\text {rd }}$ Regional Higher Education Conference}

The Regional Higher Education Conferences (CRES) constitute the mechanism for concerting public and institutional policy recommendations for this most ambitious and influential level of education available in Latin America and the Caribbean. 
To date, three of these conferences have been held. The first of these was held in Havana, Cuba, in 1996, the second in Cartagena de Indias, Colombia in 2008, and the third in Córdoba, Argentina in 2018. Each of these conferences has brought together the higher education authorities of all the governments of the region, as well as the authorities of a large part of the universities of these countries, specialists in the subject, leaders of union and student organizations. Each of these meetings produced a declaratory final document and a set of recommendations.

In recognition of the problems affecting Higher Education discussed in previous sections of this text, as well as the advances referred to above, the final statement of the 2nd CRES highlighted the problems derived from the monocultural nature of Higher Education and the need to advance in the types of transformations that were already underway. But the final document of the $3 \mathrm{rd} \mathrm{CRES}^{7}$ went further and also emphasized the need to eradicate racism and racial discrimination (Mato, 2018a).

Due to its importance, it is worth quoting a relatively long extract of the main recommendations of the 3rd CRES Declaration:

Higher education policies and institutions must proactively contribute to dismantling all the mechanisms that generate racism, sexism, xenophobia, and all forms of intolerance and discrimination. It is imperative that the rights of all population groups discriminated by race, ethnicity, gender, socioeconomic status, disability, sexual orientation, religion, nationality and forced displacement be guaranteed.

It is necessary to promote cultural diversity and interculturality in equitable and mutually respectful conditions. The challenge is not only to include women, people with disabilities, members of indigenous and Afro-descendant peoples and individuals from historically discriminated social groups in higher education institutions, but to transform them to be socially and culturally relevant.

These changes must ensure the incorporation in the institutions of higher education of the world views, values, knowledge, knowledge, linguistic systems, forms of learning and ways of producing knowledge of these peoples and social groups.

\footnotetext{
7 The Final Declaration of CRES 2018 is available at: http://espacioenlaces.org/declaracion-cres-
} 2018/; recuperado 14-12-2019. 
It is inescapable to recognize and value the epistemologies, learning modes and institutional designs of indigenous and Afro-descendant peoples, peasant communities and other socio-culturally differentiated ones.

There is a significant historical debt of Latin American and Caribbean states and societies to indigenous and Afro-descendant peoples. Although their rights are recognized in numerous international instruments and in most national constitutions, there is an alarming deficit in their effective enjoyment, even in higher education. Higher education institutions must guarantee the effective enjoyment of these rights and educate the population in general, and particularly their communities, against racism and all forms of discrimination and related forms of intolerance.

It is essential to promote and facilitate the learning of the languages of indigenous and Afro-descendant peoples and their effective use in teaching, research and extension practices. The training of bilingual intercultural teachers for all levels of the educational systems is a priority duty of higher education.

The challenge is to put these recommendations into practice in all universities and other HEIs in Latin America, and more broadly in the Higher Education systems of the respective countries. This entails important challenges for all the actors in the Higher Education systems of the region and demands expanding and deepening the work in networks of mutual collaboration that, increasingly, has been developing since the end of the 1990s (Mato, 2018b). Along with this, it is necessary to systematically work on promoting public reflections and debates on the subject, as well as educating the population in general and particularly all the actors of the educational systems, especially those of Higher Education, against racism, with the leading participation of students and referents of communities and organizations of indigenous and Afro-descendant peoples.

\section{References}

Ardao, A. (1980) Génesis de la idea y el nombre de América Latina. Caracas: Centro de Estudios Latinoamericanos Rómulo Gallegos.

Baronnet, B y Bermúdez Urbina, F.M., coords. (2019) La vinculación comunitaria en la formación de profesionales indígenas en México. México: ANUIES. 
The multiple forms of racism $\mid 48$

CGEIB - Coordinación General De Educación Intercultural Bilingüe, COMP. (2004), Educación superior para los pueblos indígenas de América Latina. Memorias del Segundo Encuentro Regional. México: CGEIB, Secretaría de Educación Pública (SEP).

Di Caudo, M. V.; Llanos Erazo, D. y Ospina Alvarado, M. C., Coords. (2016) Interculturalidad y educación desde el sur. Contextos, experiencias y voces. Quito: Abya Yala y Universidad Politécnica Salesiana.

Hernández Loeza, S., Ramírez Duque, M.I., Manjarrez Martínez, Y. y Flores Rosas, A. Coords. (2013) Educación Intercultural a Nivel Superior: Reflexiones desde diversas realidades latinoamericanas. Huehuetla (Puebla, México): Universidad Intercultural del Estado de Puebla.

Mato, D. (2015) Vinculación social universitaria en Argentina. Diversidad de orientaciones de trabajo, logros y dificultades de las experiencias apoyadas por el Programa Nacional de Voluntariado Universitario. CPU-e, Revista de Investigación Educativa (Universidad Veracruzana, México) Vol. 20: 132 - 149.

Mato, D. (2018A) Diversidad Cultural e Interculturalidad en la III Conferencia Regional de Educación Superior - CRES 2018. Integración y Conocimiento (Universidad Nacional de Córdoba) 7(2):37-61

Mato, D. (2018B) Educación Superior y Pueblos Indígenas y Afrodescendientes en América Latina: Tendencias en curso, tensiones, posibilidades y desafíos. En: Pedro Henríquez Guajardo (coord.) Tendencias de la educación superior en América Latina y el Caribe 2018 - 2028. Caracas: UNESCO - IESALC y Córdoba: Universidad Nacional de Córdoba. Págs.: 59 - 109.

Mato, D., Coord. (2008) Diversidad cultural e interculturalidad en Educación Superior. Experiencias en América Latina. Caracas: Instituto Internacional de la UNESCO para la Educación Superior en América Latina y el Caribe (UNESCOIESALC)

Mato, D., Coord. (2009) Instituciones Interculturales de Educación Superior en América Latina. Procesos de Construcción, Logros, Innovaciones y Desafíos. Caracas: UNESCO-IESALC.

Mato, D., Coord. (2015) Educación Superior y Pueblos Indígenas. Contextos y Experiencias. Sáenz Peña (Pcia. de Buenos Aires): Editorial de la Universidad Nacional de Tres de Febrero - EDUNTREF. 
Mato, D., Coord. (2016) Educación Superior y Pueblos Indígenas en América Latina. Experiencias, interpelaciones y desafíos. Sáenz Peńa (Pcia. de Buenos Aires): EDUNTREF y México: Universidad Nacional Autónoma de México - UNAM

Mato, D., Coord. (2017) Educación Superior y Pueblos Indígenas en América Latina. Políticas y prácticas de inclusión, democratización e interculturización. Sáenz Peña (Pcia. de Buenos Aires): EDUNTREF y José María Morelos, Q.R., México: UIMQRoo

Mato, D., Coord. (2018A) Educación Superior y Pueblos Indígenas en América Latina. Políticas y experiencias de inclusión y colaboración intercultural: Sáenz Peña (Pcia. de Buenos Aires): EDUNTREF.

Mato, D., Coord. (2019) Educación Superior y Pueblos Indígenas en América Latina. Colaboración intercultural: experiencias y aprendizajes. Sáenz Peña (Pcia. de Buenos Aires): EDUNTREF.

ONU - Organización De Naciones Unidas. 2002. Declaración y Programa de Acción de la Conferencia Mundial contra el Racismo, la Discriminación Racial, la Xenofobia y las Formas Conexas de Intolerancia. Disponible: https://www.ohchr.org/Documents/Publications/Durban_text_en.pdf

ONU - Organización De Naciones Unidas. 2005. "Report of the Special Rapporteur on the situation of human rights and fundamental freedoms of indigenous people, Rodolfo Stavenhagen (E/CN.4/2005/88). Disponible: https:/www.rightdocs.org/doc/a-hrc-4-32/ 